\title{
A bridge too far?
}

\author{
Ross M. Reul, MD, and Michael J. Reardon, MD
}

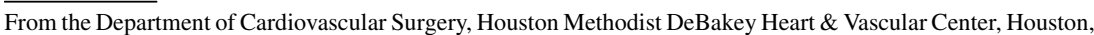 \\ Tex. \\ Disclosures: Authors have nothing to disclose with regard to commercial support. \\ Received for publication Dec 13, 2016; accepted for publication Dec 19, 2016; available ahead of print January \\ $25,2017$. \\ Address for reprints: Michael J. Reardon, MD, Houston Methodist DeBakey Heart \& Vascular Center, 6550 \\ Fannin St, Suite 1401, Houston, TX 77030 (E-mail: Mreardon@houstonmethodist.org). \\ J Thorac Cardiovasc Surg 2017; 153:e65 \\ $0022-5223 / \$ 36.00$ \\ Copyright (C) 2016 by The American Association for Thoracic Surgery \\ http://dx.doi.org/10.1016/j.jtcvs.2016.12.018
}

Soft tissue sarcoma occurs in more than 8000 patients per year in the United States. Local control can often be achieved in soft tissue sarcoma, but metastatic disease continues to occur in $25 \%$ to $50 \%$ of afflicted patients. Because of the tumor's propensity for hematogenous spread, the most common site of metastatic involvement is the lung. Patients with local control of their initial tumor but with pulmonary metastasis will generally show less than $20 \%$ survival at 5 years without surgery, compared with slightly more than $50 \%$ survival with pulmonary metastasectomy. ${ }^{1}$ Pulmonary metastasectomy is considered if the local tumor is controlled, the metastatic disease can be completely removed, and the risk to the patient is reasonable. Positive prognostic factors for survival are 2 or fewer metastatic lesions, no lesions larger than $2 \mathrm{~cm}$, and no disease outside of the lungs; the number of pulmonary metastases is the strongest predictor. ${ }^{1}$

Hashimoto and co-authors ${ }^{2}$ present a 38 -year-old man who had complete resection of a right hip osteosarcoma 16 months before presentation with hemoptysis. His physicians discovered an 11-cm right lower lobe lesion that also involved his left atrium and a 4-cm lesion in the left lower lobe. He underwent palliative intent radiation of $20 \mathrm{~Gy}$ to the right-sided lesions. Once the hemoptysis resolved, the patient was treated with 6 rounds of neoadjuvant chemotherapy with adriamycin and ifosfamide. After chemotherapy, the patient's lung lesions were reduced, and he was without extrapulmonary disease. With 2 of the 3 positive aforementioned prognostic factors, surgical resection would be reasonable if the team could completely resect both lesions with negative margins and at a reasonable level of risk to the patient. The surgical team operated using a well-thought-out strategy to achieve this goal; their method is worth considering by serious thoracic surgeons.

"A Bridge Too Far" refers to the 1974 book by Cornelius Ryan $^{3}$ that tells the story of the failure of Operation Market Garden in World War II. The Allies planned to capture a number of key bridges in the occupied Netherlands, hoping to outflank the German defense forces and end the war before Christmas. The title references a quote from a commander who worries his troops will not be able to seize all

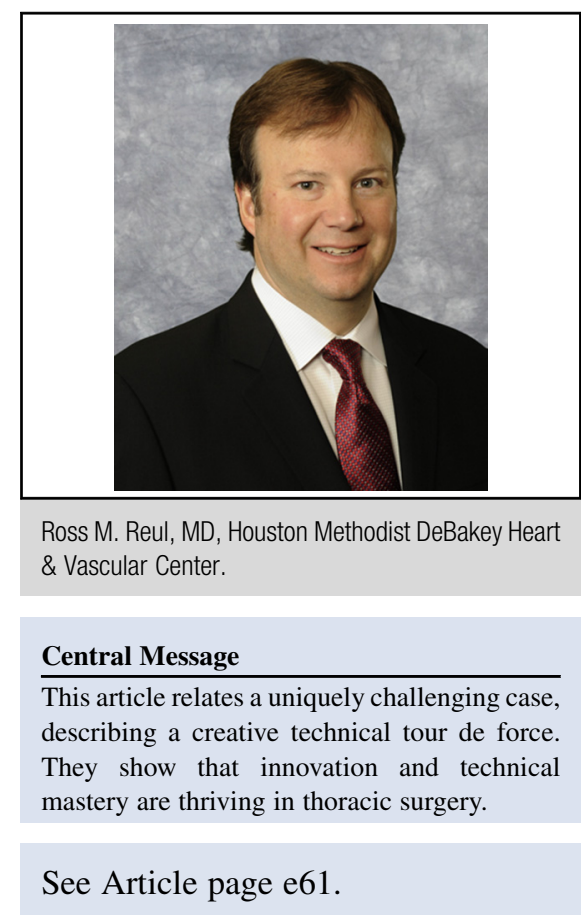

the targeted bridges and fears they may be going "a bridge too far." Thus, "a bridge too far" has come to mean exceeding one's capacity for success.

Our thoracic tumor group has considerable experience with tumors requiring both cardiac and pulmonary resection $^{4}$ and lung cancer requiring simultaneous cardiac resection. ${ }^{5}$ These are challenging cases, and strategic planning is imperative. Hashimoto and co-authors ${ }^{2}$ describe an innovative approach to this difficult problem and achieved an outstanding outcome. Although we-and you-might have taken a different approach, these cases demonstrate how the innovative thinking of thoracic surgeons when faced with difficult and unusual problems can save the day. We congratulate Dr Hashimoto and colleagues ${ }^{2}$ on successfully outflanking the sarcoma. Through strategy and skill, they saved the patient and avoided going a bridge too far.

\section{References}

1. Predina JD, Puc MM, Bergey MR, Sonnad SS, Kucharczuk JC, Staddon A, et al Improved survival after pulmonary metastasectomy for soft tissue sarcoma. J Thorac Oncol. 2011;6:913-9.

2. Hashimoto K, Stansfield W, Keshavjee S. Pulmonary and atrial resection and reconstruction for sarcoma with intracardiac extension. J Thorac Cardiovasc Surg. 2017;153:e61-3.

3. Ryan, C. A Bridge Too Far. 1st ed. NY: Simon \& Schuster; 1995

4. Ramlawi B, Leja MJ, Abu Saleh WK, Al Jabbari O, Benjamin R, Ravi V, et al. Surgical treatment of primary cardiac sarcomas: review of a single-institution experience. Ann Thorac Surg. 2016;101:698-702.

5. Ferguson ER Jr, Reardon MJ. Atrial resection in advanced lung carcinoma under total cardiopulmonary bypass. Tex Heart Inst J. 2000;27:110-2. 